\title{
Correction: The International Federation for Emergency Medicine report on emergency department crowding and access block: $A$ brief summary
}

Javidan AP, Hansen K, Higginson I et al. The International Federation for Emergency Medicine report on emergency department crowding and access block: A brief summary. Emerg Med J 2021;38:245-46.

Since first publication the provenance and peer review statement has been added to this article.

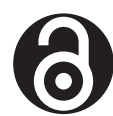

\section{OPEN ACCESS}

Open access This is an open access article distributed in accordance with the Creative Commons Attribution 4.0 Unported (CC BY 4.0) license, which permits others to copy, redistribute, remix, transform and build upon this work for any purpose, provided the original work is properly cited, a link to the licence is given, and indication of whether changes were made. See: https:// creativecommons.org/licenses/by/4.0/.

(C) Author(s) (or their employer(s)) 2021. Re-use permitted under CC BY. Published by BMJ.

Emerg Med J 2021;0:1. doi:10.1136/emermed-2020-210716corr1

A) Check for updates 